\title{
Influence of Resilience and Self-esteem among Undergraduate Students in Chennai, India: An Exploratory Study
}

\author{
Lajwanti Motilal Jethwani $^{\# 1}$, Dr. R. Subhashini ${ }^{* 2}$ \\ ${ }^{1}$ Ph. D. Scholar, Department of Psychology, Bharathiar University, Tamil Nadu, India \\ ${ }^{2}$ Dean SF, Former HOD and Associate Professor, Department of Counselling Psychology, \\ Madras School of Social Works, Chennai, India
}

\begin{abstract}
This study investigate the influence of resilience and self-esteem among undergraduate college students (N=110) in Chennai district, Tamil Nadu. An exploratory design is used among undergraduate students using purposive random sampling technique. In this case, two questionnaires are administered, Self-esteem is assessed by using the Rosenberg selfesteem scale (1965) and English version of Resilience Scale - RS-14 is also used in this study (Wagnild, 2010). Correlational and regression analysis shows statistically significant relationships between resilience and self-esteem $(\mathrm{r}=0.24 * *, \mathrm{P}<0.01)$. Self-esteem can be considered a predictor of resilience, which suggests resilience based intervention, should be provided for the students to improve their self-esteem.
\end{abstract}

Keywords - Self-esteem; Resilience; College Students

\section{Introduction}

Resilience is complex and multidimensional in nature (Miller \& Daniel, 2007). It can be viewed as an outcome against the odds (Gilligan, 1997) and an adaptation process of adversity (Luthar, 2003). Miller and Daniel (2007) identified two possible sets of factors to build resilience: external and intrinsic factors. Based on their observation, external factors, such as family, friends, or school experiences, can create adversity or provide secure support and protection. In contrast, intrinsic factors include a sense of security that leads the individual to either vulnerability or resilience. Many studies have illustrated that self-esteem is a significant intrinsic factor (Fergusson and Horwood, 2003; Gilligan, 1997; Masten and Coatsworth, 1998). Consequently, self-esteem has been viewed as a personal characteristic of individuals who survive, or even thrive, in the face of adversity (Jindal-Snape\& Miller, 2008). As stated by Miller and Daniel (2007), the links between selfesteem and resilience are more numerous and more important than has previously been acknowledged. Within the school context, a wealth of research has demonstrated that resilient adolescents gain positive outcomes in their academic performance and psychosocial processes (Luthar, 2006; Luthar, Cicchetti, \& Becker, 2000; Taylor, 2010; M. C. Wang \& Gordon, 2012). Furthermore, extant research highlights the fact that resilient students tend to have high self-esteem. Miller and Daniel (2007) proposed a twodimensional model of self-esteem as a theoretical framework to revisit a range of factors frequently associated with internal resilience and argued that the links between self-esteem and resilience may have been underestimated. In line with the discussion of these theoretical issues, they provided suggestions for teachers and schools to help inform resilience-based approaches to support vulnerable children.

\section{Methods}

\subsection{Hypotheses}

On the basis of the previous discussion, four hypotheses are proposed:

H1: There is a significant positive relationship between resilience and self-esteem.

H2: There is a significant negative relationship between Self-esteem and academic performance.

H3: There is a significant positive relationship between resilience and academic performance.

H4: There is a significant difference between sociodemographic variable, resilience and self-esteem.

\subsection{Participants and procedure}

The present study followed the exploratory study design. The participants are the students of Bachelor of Arts \& Science in various colleges in Chennai district, Tamil Nadu. There are 250 undergraduate students in the college. Total enumeration method is used for the selection of the college students. After the removal of incomplete surveys, the final sample is of 110 students with an age average $\mathrm{M}=18.80$ (S.D. $=0.73$ ) of which 45 men and 65 women, without significant difference concerning the average age. The consent is taken from the principle to carry out a research study. The survey is administered at the end of a seminar during a period of 20-25 minutes and the students informed on the confidentiality of the results. 


\section{Tools of Data Collection}

\subsection{Rosenberg Self-Esteem Scale}

Description: This 10-item scale assesses an individual's feelings of self-worth when the individual compares himself or herself to other people. The scale is an effort to attain one-dimensional estimate of global selfesteem. It is developed to represent a range of self-worth, with statements of the low self-esteemed person to the statements of high self-esteemed persons. The scale may also be customized to calculate the self-esteem by asking the participants to replicate on their current feelings.

Reliability: A correlation of minimum 0.80 is recommended for any one case of reliability as evidence. Though, the basic range from 0.5 to 0.9 depends on the planned use and context for the instrument. Internal Consistency: Ranges from 0.77 to 0.88 . Inter-rater reliability: No information provided Test-Retest: Ranges from 0.82 to 0.85 .

Validity: The extent to which a measure captures what it is intended to measure. Content/Face Validity: No information is given, Criterion Validity: 0.55 Construct Validity: Correlated - 0.64 with anxiety, - 0.54 with depression, and -0.43 with anomie.

Scoring: 2, 5, 6, 8, 9 are scored in reverse. 1 point is given for "Strongly Disagree", 2 point is for "Disagree" 3 point is given to "Agree", and 4 point is for "Strongly Agree". Sum scores for all ten items. Keep scores on a continuous scale. Higher scores indicate higher self-esteem.

\subsection{Resilience Scale - RS-14 (Wagnild, 2010)}

The used RS-14 is the adaptation procedure developed by Pesce et al. (2005), in which Brazilian sample are used to RS-25 for translate and validate. For the objective of this study, the nine items of the RS-25 that did not compose the reduced version are deleted. The present version of the RS14 consists of five objects that referring to "self-reliance" $(1,5,7,12$, and 14), three objects that referring to "meaningfulness" (2, 9, and 13), two objects that referring to "equanimity" ( 3 and 10), two objects that referring to "perseverance" (6 and 8), and two objects that referring to "existential aloneness" (4 and 11). The participants rate the objects on a scale from 1 (strongly disagree) to 7 (strongly agree).

\subsection{Demographic Variables}

Socio-demographic Performa is constructed to collect data regarding the domains like age, sex, class, family details, academic performance, and other details.

\section{Result}

Table 1: Frequency and percentage of demographic variables of undergraduate students

\begin{tabular}{|l|l|l|l|}
\hline \multicolumn{1}{|c|}{ Variables } & & $\mathbf{N}$ & \% \\
\hline \multirow{2}{*}{ Gender } & Male & 45 & 41 \\
\cline { 2 - 4 } & Female & 65 & 59 \\
\hline \multirow{3}{*}{ Religion } & Hindu & 65 & 59 \\
\cline { 2 - 4 } & Christian & 25 & 23 \\
\cline { 2 - 4 } & Muslim & 20 & 18 \\
\hline \multirow{4}{*}{ Education } & Sociology & 40 & 36 \\
\cline { 2 - 4 } & Physics & 35 & 32 \\
\cline { 2 - 4 } & Mathematics & 35 & 32 \\
\hline \multirow{3}{*}{ Economily Type Status } & Nuclear & 75 & 68 \\
\cline { 2 - 4 } & Joint & 35 & 32 \\
\cline { 2 - 4 } & Lower Middle & 27 & 25 \\
\cline { 2 - 4 } & Upper Middle & 64 & 58 \\
\cline { 2 - 4 } & Upper & 19 & 17 \\
\hline
\end{tabular}

Table 1 shows the demographic details of the undergraduate students. In the study majority of the participants are female (59\%). On religion, $59 \%$ belongs to Hindus, $23 \%$ belongs to Christian and $18 \%$ belongs to Muslim. $68 \%$ of the students live in nuclear family whereas $32 \%$ lives in joint family.

Table 2: Correlation matrix for resilience, self-esteem and age

\begin{tabular}{|l|c|c|c|}
\hline Variables & Resilience & Self-esteem & Age \\
\hline Resilience & - & $0.24^{* *}$ & $0.53^{* *}$ \\
\hline Self-esteem & $0.24^{* *}$ & - & $0.35^{* *}$ \\
\hline Age & $0.53^{* *}$ & $0.35^{* *}$ & - \\
\hline
\end{tabular}

Results given in table 2 showed that resilience was positively and significantly related with self-esteem ( $\mathrm{r}=$ $\left.0.24^{* *}, \mathrm{P}<0.01\right)$ and age $\left(\mathrm{r}=0.53^{* *}, \mathrm{P}<0.01\right)$, In addition, Self-esteem was positively and significantly related with age $\left(\mathrm{r}=0.35^{* *}, \mathrm{P}<0.01\right)$ (See table 2$)$.

Table 3: Gender difference on Resilience and Self-esteem $(\mathrm{N}=110)$

\begin{tabular}{|l|c|c|c|c|c|l|}
\hline & \multicolumn{2}{|c|}{$\begin{array}{c}\text { Male } \\
(\mathrm{N}=45)\end{array}$} & \multicolumn{2}{|c|}{$\begin{array}{l}\text { Female } \\
(\mathrm{N}=65)\end{array}$} & & \\
\hline Variable & $\boldsymbol{M}$ & SD & $\mathbf{M}$ & SD & $\begin{array}{l}\mathbf{t}- \\
\text { value }\end{array}$ & $\begin{array}{l}\text { p- } \\
\text { value }\end{array}$ \\
\hline $\begin{array}{l}\text { Self- } \\
\text { Esteem }\end{array}$ & 4.12 & 0.73 & 3.92 & 0.79 & 9.16 & $0.00^{* *}$ \\
\hline $\begin{array}{l}\text { Resilienc } \\
\mathrm{e}\end{array}$ & 3.63 & 0.99 & 3.40 & 1.01 & 10.4 & $0.00 * *$ \\
\hline
\end{tabular}

Results presented in Table 3 showed that male undergraduate students significantly score higher than 
female employees on self-esteem $(\mathrm{t}$-value $=9.16, \mathrm{p}$ value $=$ $\left.0.00^{* *}\right)$, and resilience $\left(\mathrm{t}\right.$-value $=10.4, \mathrm{p}$-value $\left.=0.00^{* *}\right)$.

Table 4: Distribution of Resilience and Self-esteem among undergraduate's students

\begin{tabular}{|l|c|c|c|c|c|}
\hline $\begin{array}{l}\text { 'Variabl } \\
\text { e }\end{array}$ & $\begin{array}{c}\text { Very } \\
\text { High }\end{array}$ & High & $\begin{array}{c}\text { Aver } \\
\text { age }\end{array}$ & Low & $\begin{array}{c}\text { Very } \\
\text { Low }\end{array}$ \\
\hline $\begin{array}{l}\text { Resilienc } \\
\text { e }\end{array}$ & 10 & 15 & 40 & 35 & 10 \\
$(9 \%)$ & $(14 \%)$ & $(36 \%)$ & $(32 \%)$ & $(9 \%)$ \\
\hline & \multicolumn{2}{|c|}{ Low } & \multicolumn{2}{|c|}{ Average } & High \\
\hline $\begin{array}{l}\text { Self- } \\
\text { esteem }\end{array}$ & & 40 & \multicolumn{2}{|c|}{5} & $\begin{array}{l}55 \\
(50 \%)\end{array}$ \\
$(14 \%)$
\end{tabular}

In resilience, $14 \%$ high resilience, $36 \%$ average resilience, $32 \%$ low resilience, and $10 \%$ is having very low resilience. In self-esteem, $18 \%$ of the respondents has low self-esteem, $55 \%$ average self-esteem, $35 \%$ is having high self-esteem (Table 2).

Table 5: Regression analysis summary of self-esteem on resilience

\begin{tabular}{|c|c|c|c|c|c|}
\hline & df & SS & MS & $\begin{array}{c}\text { F- } \\
\text { value }\end{array}$ & p-value \\
\hline Regression & 3 & 6627.946 & 1656.98 & & \\
\hline Residual & 110 & 68981.453 & 213.765 & 5.876 & $0.000 * *$ \\
\hline $\mathbf{R}$ & $\mathbf{R}^{2}$ & Adjusted & \multicolumn{3}{|c|}{ Standard } \\
\hline 0.265 & 0.088 & 0.075 & \multicolumn{3}{|c|}{15.345} \\
\hline Variables & B & Std error & Beta & $\begin{array}{c}\text { t- } \\
\text { value }\end{array}$ & p-value \\
\hline $\begin{array}{l}\text { Self- } \\
\text { Esteem }\end{array}$ & 1.010 & 0.216 & 0.256 & 4.553 & $0.000 * *$ \\
\hline
\end{tabular}

As shown in the regression summary table (5) above, the regression model that included Self-esteem. Selfesteem variables contributed significantly to the prediction of overall resilience of undergraduate students $(\mathrm{F}(3,110)=$ $5.876, \mathrm{p}<0.05$ accounting for 8.8 percent variance. The remaining 91.2 percent is attributed to variables not included in the study. Self-esteem strongly contributed to the variance on the overall resilience score (Beta $=-0.256$, $\mathrm{t}=4.553 \mathrm{p}=.000)$.

\section{Discussion}

The primary objective of this study is to explore the influence of self-esteem and resilience among undergraduate students. In this present study, majority of the participants are female $(59 \%)$. On religion, $59 \%$ belongs to Hindus, 23\% belongs to Christian and $18 \%$ belongs to Muslim. 68\% of the students live in nuclear family whereas $32 \%$ lives in joint family. The present study reveals the gender difference on self-esteem and resilience. The result shows that male undergraduate students significantly score higher than female students on self-esteem and resilience. Similar study conducted by
Saari, \& Judge (2004), found that there is a significant difference between male and female on resilience and selfesteem. On that male adolescents score higher than the female.

The present study find that more than half of the participants 55\% are having an average level of self-esteem whereas $36 \%$ of the students fall under low self-esteem. Similar study found that there is one third of the students are having low self-esteem, because of less attentive toward their goal, lack of involvement in career oriented activities, lack of family support, are more pessimist and experience low level of selfesteem (Shaheen, 2015). In the current study, there is a significant positive correlation between self-esteem and resilience ( $\mathrm{r}=0.24, \mathrm{p}=0.05)$. Hjedmdal et al. (2006) stated that higher levels of resilience had been associated with higher levels of selfesteem among university students. Desrosiers et al. (2013) found that university students with higher levels of selfesteem have reported higher levels of resilience. Stallman (2010) described that the resilience in students help to acclimatize and adjust with stressors unique to university life and avoid psychological distress.

An important association between self-esteem and resilience score is found in regression analysis. Kapikiran and Acun-Kapikiran (2016) found that self-esteem is a full mediator of resilience. The self-esteem and resilience relationship is logically supported by self consistency theory where individuals with higher self-esteem showing good recital according to their interest, that leads to greater satisfaction (see Ferris, Lian, Brown, Pang,\& Keeping, 2010). In a study adolescents, Leung et al. (2005) argue that resilience enhances self-esteem because resilience are more hopeful about future so they are motivated to capitalize in personal development. In addition, resilience are more disposed to accept facts and reality (Scheier et al., 1986; Taylor, 1983; Taylor et al., 1989). Jackson et al. (2005) document that resilience and self-esteem both reinforces each other as both are in viable mutual relationship. Locke et al. (1996) identified that those with high self-esteem think of a complicated job as an opportunity to learn and gain from it while, the others having low self-esteem take it as an unjustified one or an opportunity to fail.

\section{Limitations and Suggestions}

The current study has several limitations. First, the exploratory survey data is used in this study due to which causal relationship cannot be inferred. The future researches should adopt a longitudinal strategy to confirm the direction of causation. Second, data are mainly from undergraduate student. Future studies could examine whether the relationships found out in this study should be generalized to sample of other level of college students. 
Studies should also be conducted to see the impacts of demographic characteristics in the relationship between resilience and self-esteem.

\section{Conclusion}

The present study extends earlier researches by providing first evidence for the mediating role of positive internal dispositional factors in the relationship between self-esteem and resilience. The current findings suggest that resilience may act as an accelerator to improve selfesteem. From adolescent behavior perspective, these findings suggest that resilience may be a more beneficial asset for the students to improve their academic performance. Students with higher self-esteem, resiliency is more likely to experience greater academic satisfaction in comparison to those who have lower level of these traits. The good thing is that these dispositional traits can be developed in individuals.

\section{References}

[1] Miller, D., \& Daniel, B. (2007). Competent to cope, worthy of happiness? How the duality of self-esteem can inform a resiliencebased classroom environment. School Psychology International, 28, 605-622

[2] Luthar, S. S. (Ed.). (2003). Resilience and vulnerability: Adaptation in the context of childhood adversities. Cambridge, UK: Cambridge University Press

[3] Gilligan, R. (1997). Beyond permanence? The importance of resilience in child placement practice and planning. Adoption \& Fostering, 21(1), 12-20

[4] Fergusson, D. M., \&Horwood, L. J. (2003). Resilience to childhood adversity: Results of a 21-year study. In S. S. Luthar (Ed.), Resilience and vulnerability: Adaptation in the context of childhood adversities (pp. 130-155). New York, NY: Cambridge University Press.

[5] Masten, A. S., \&Coatsworth, J. D. (1998). The development of competence in favorable and unfavorable environments: Lessons from research on successful children. American Psychologist, 53(2), 205-220
[6] Luthar, S. S., Cicchetti, D., \& Becker, B. (2000). The construct of resilience: A critical evaluation and guidelines for future work. Child Development, 71, 543-562.

[7] Taylor, R. D. (2010). Risk and resilience in low-income African American families: Moderating effects of kinship social support. Cultural Diversity Ethnic Minority Psychology, 16(3), 344-351.

[8] Wang, M. C., \& Gordon, E. W. (2012). Educational resilience in inner-city America: Challenges and prospects. New York, NY: Routledge.

[9] Saari, L. M., \& Judge, T. A. (2004). Employee attitudes and job satisfaction. Human Resource Management, 43(4), 395-407.

[10] Hjemdal O, Friborg O, Stiles T C, Rosenvinge J H. \&Martinussen M. Resilience predicting psychiatric symptoms: A prospective study of protective factors and their role in adjustment to stressful life events. Clinical Psychology and Psychotherapy. 2006;13:194- 201. Available in http://dx.doi.org/10.1002/cpp.48

[11] Shaheen F. Study of Optimism and Self Esteem in Relation to Psychological Distress Among Professional and Nonprofessional Students, International Journal of Education and Psychological Research (IJEPR). 2015;4(1).

[12] Desrosiers A, Klemanski D H, \& Nolen-Hoeksema S. Mapping mindfulness facets onto dimensions of anxiety and depression. Behavior Therapy. 2013;44:373-384. Available in http://dx.doi.org/10.1016/j.beth.2013.02.001

[13] Stallman H. M. Psychological distress in university students: A comparison with general population data. Australian Psychologist. 2010;45:249- 257. Available in http://dx. doi.org/ 10.1080/00050067.2010.482109

[14] Kapıkıran Ş, \&Acun-Kapıkıran N. Optimism and psychological resilience in relation to depressive symptoms in university students: Examining the mediating role of self-esteem. Educational Sciences: Theory \& Practice. 2016;16:2087-2110.

[15] Leung, B.W., Moneta, G. B., \& McBride-Chang, C. (2005). Think positively and feel positively: Optimism and life satisfaction in late life. International Journal of Aging and Human Development, 61(4), 335-365.

[16] Scheier, M. F., Weintraub, J. K., \& Carver, C. S. (1986).Coping with stress: Divergent strategies of optimists and pessimists. Journal of Personality and Social Psychology, 51, 1257-1264.

[17] Taylor, S. E. (1983). Adjustment to threatening events: A theory of cognitive adaptation. American Psychologist, 38, 1161-1173.

[18] Taylor, S. E., Collins, R. L., Skokan, L. A., \&Aspinwall, L. G. (1989). Maintaining positive illusions in the face of negative information: Getting the facts without letting them get to you. Journal of Social and Clinical Psychology, 8, 114-129.

[19] Locke, E. A., McClear, K., \& Knight, D. (1996). Self-esteem and work. International Review of Industrial Organizational Psychology, 11, 1-32. 